extended over a period of eight-nine months, and were immediately followed by Younghusband's famous journey across Central Asia from Peking to India, culminating in the crossing of the hitherto unknown Mustagh Pass into Baltistan. This journey is de. scribed in his own book "The Heart of a Continent", one of the classics of Asiatic (or indeed of any) travel, admirable alike both for the intrinsic interest of the journey itself and for the style in which the book is written. The publication of this book at once placed Younghusband in the foremost ranks of contemporary travellers and writers.

From this on his active life, both as an officer of the Indian Foreign and Political Department and as a traveller, continued almost without a pause until his retirement on pension in 1910. During the years 1888-91 he made a series of journeys through the wild areas of Central Asia, the Pamirs, Kashgaria, and certain hitherto unexplored tracts lying to the north of the Karakoram and Mustagh ranges. These journeys had a political as well as a geographical interest and importance. Later he served in Chitral, and travelled in South Africa as The Times correspondent just prior to the outbreak of the Boer War.

Younghusband was thus a well-known figure with a world-wide reputation when, early in 1903 , he was appointed by the Viceroy, Lord Curzon, as commissioner in charge of the projected mission to Tibet, then in process of preparation on the Darjeeling frontier.

It was here that I first met him, and in the capacity of secretary and interpreter to the mission I was constantly by his side until he returned to India some sixteen months later on the conclusion of his task, and I was thus able to get to know him intimately and to appreciate his character and his capabilities. A man's character may often, I think, be estimated not so much from his conduct on the great occasions and crises of his life as from his reactions to the petty affairs of everyday and the small worries and mishaps inevitable during travel or a military expedition. Of these we had our full share during the mission-cold, fatigue, boredom, and at times danger and excitement. During all these critical months, when the chief responsibility for success or failure rested on his shoulders, I never once saw him, even for a moment, in the slightest degree flurried, impatient, cross, or in any way perturbed. He remained always cheerful and goodhumoured, and apparently indifferent to the small matters which affect ordinary mortals. This was not a pose. It was an attitude of mind based upon his essential equanimity. He knew very well what he wanted and how he proposed to get it, and having thought all this out carefully he was able to relegate all minor considerations to their proper place. But at the same time when any major difficulty or danger, or difference of opinion arose which seemed likely to interfere with his plans or the progress of the mission, he was persistent, inflexible and courageous to a degree.

It was, in fact, greatly due to this combination of qualities-on one hand infinite patience where patience and conciliation appeared advisable, and on the other readiness to fight and to accept risks and responsibilities at critical moments - that our mission succeeded as it did.

It is an old story now and has often been told, but it should be remembered that it was not an easy business. The Tibetans were obstinate and pugnacious ; and the dispatch of a mission with a small military escort into the depths of Asia, hundreds of miles beyond the Himalayas, and separated from its base by several lofty mountain passes and (when at Lhasa) by a great unbridged river, resembled more the adventures of Cortes or Pizarro than modern military and diplomatic procedure. There were occasions when failure seemed imminent and in. evitable. But, as I have remarked above, it was the combined tact and firmness of the Commissioner which always overcame the crisis, and which even. tually secured not merely a favourable treaty with the Tibetans but also the goodwill and friendship which have lasted from that day to this.

I have dwelt at some length on this Tibetan affair, partly because it is the culminating point in Young. husband's career as a man of action, and partly because it presented such an opportunity for the exercise of his peculiar qualities. He retired from the service a few years later, and during the remainder of his life devoted himself to work with the Royal Geographical Society, the organization of the Mount Everest expeditions, and to writing.

During these latter years he published a number of volumes dealing with his favourite subjects: the beauties of Nature, Indian aspirations, and philosophical musings and conclusions. Of these latter the volume which perhaps summarizes most fully the general trend of his mind is "The Living Universe", published in 1933. In this book he traces the genesis and development of this planet from fiery vapour to the present day, and he outlines his conclusions on the vexed and oft-debated question of the origin and evolution of life and intelligence from apparently dead matter. Space does not permit of any attempt to follow him in this thesis, but a perusal of the book will give a good general conception of his attitude towards such questions and the evolution of higher types of beings on this and possibly on other planets; and in some most interesting passages he reveals certain mystical experiences which have come to him.

It was during these latter years, too, that Younghusband organized the World Congress of Faiths, representing all the world's chief religions. The catholicity of his views, and the wide respect which these views commanded, were well illustrated in the memorial service held at St. Martin-in-the-Fields on August 10 when, besides the customary Christian prayers and hymns, extracts from the Hindu, Jewish, Buddhist and Moslem scriptures were read by representatives of each of these faiths.

Such a character is rare, and when his achievements as a soldier, explorer and diplomat are borne in mind, perhaps unique. His friends will always remember him with affection for his patience, tolerance, good humour, simplicity and utter sincerity.

Frederick O'CONNOR.

\section{Mr. D. B. Mair}

David Beveridge Matr, who died at Galashiels on July 21, was well known as a mathematician and was a distinguished member of the Civil Service. He was born in Canada on March 24, 1868. His father, who was a Presbyterian minister, of an Aberdeen family, died young. David Mair was at school at Dollar Academy. At the age of sixteen he entered the University of Edinburgh and obtained first class honours in mathematics and in natural philosophy. He went to Cambridge as a scholar of Christ's, and was second wrangler in 1891. In 1893 he was awarded a 
Smith's Prize and in 1894 was elected a fellow of Christ's.

During the next two years, part of Mair's time was spent in study abroad, particularly in Germany, and part in lecturing to honours students at University College, London, under Prof. Karl Pearson. In 1896 he was appointed a junior examiner in the Civil Service Commission; from that time, although he kept up his mathematical studies (including that of relativity), he devoted almost the whole of his energy to his official work. He had a powerful and original mind and would undoubtedly have done valuable work in mathematics in the greater freedom of an academic career. However, he found adequate scope for his abilities in the many problems arising out of the work of the Commission; he became head of the examination branch in 1907 and in 1918 was also appointed an assistant commissioner.

By nature Mair was an ardent reformer; but to the zeal of a missionary he added the remorseless logic of a mathematician and the open-mindedness of a scientific investigator. His prentice hand he tried on the mathematical question papers of school standard, eliminating book work and formal questions such as "solve the equation ....", and substituting problems, particularly those of a practical nature on matters of everyday life. All candidates were required to use mathematical instruments and in some schemes of examination, for example, Army Entrance, laboratory tests in mathematics were added. For these tests he developed a fully equipped laboratory for the simultaneous examination of a number of candidates. As opportunity arose he endeavoured to get the syllabuses changed by removing the icy hand of Euclid and cutting out dead wood. At a later date somewhat similar treatment was accorded to the examinations of higher standard. There is little doubt that his efforts had a very considerable effect in improving mathematical teaching in Great Britain.

In course of time similar ideas were applied to other subjects, such as natural science, modern languages, etc. Nothing was too small to escape his eagle eye and fertile brain. For example, he devoted much time to drafting a syllabus in handwriting and devising a scheme by which a candidate could obtain full marks for a clear workaday hand, instead of spending laborious hours in order to produce in the examination room a beautiful specimen of what was known as the "Civil Service hand"; for spelling he evolved a type of question paper on a phonetic basis for which he designed some special symbols.

Naturally, he gave much attention to wider problems such as the drafting of schemes of examination and the adjustment of candidates' marks. As regards the latter subject, the methods used in the Commission were far in advance of those of other examin. ing bodies; little information was published but particulars were readily given to inquirers.

In drafting schemes of examination, Mair endeavoured to bring them into close connexion with the educational system of the country, so that candidates could take the Civil Service examinations in their stride without special preparation at school or college, or recourse to a crammer. Besides the advantage to the candidate, this procedure widened the field and was thus of benefit to the State. He was also strongly in favour of selecting candidates of mature age by interview and record instead of by a written examination-the traditional Civil Service procedure. Further, he was always prepared to experiment with new methods, such as intelligence tests, to devise means of estimating their value, and to discard them if they proved useless.

A great impetus was given to the improvement of the examination methods of the department by the appointment of Mr. (later Sir) Stanley Leathes as first commissioner. He was a man of great ability and wide knowledge, an experienced examiner, and much interested in educational matters, particularly in the teaching of modern languages. In 1919 the Treasury set up a committee to consider the scheme of examination for Class I clerkships, the highest grade in the Civil Service, with Leathes as chairman and Mair as secretary. This Committee produced a very interesting report and recommended many important changes, including the introduction of a viva voce test and elementary papers in English, general knowledge, a foreign language and elementary science, in addition to advanced papers in the candidates' special subjects. The scheme, with certain variations, was adopted for the whole administrative group, namely, Class I clerkships, appointments in the Indian Civil Service, Foreign Office clerkships, etc.

During the War of 1914-18, Mair assisted Sir Alfred Ewing in the Intelligence Department of the Admiralty in deciphering intercepted German code messages. In 1921 he went to India to preside at the first examination held in that country for appointments to the Indian Civil Service.

Mair retired from the Civil Service in 1933 on reaching the age limit, and since then spent much time travelling abroad. He was a singularly modest man and never courted publicity. Small of stature but stoutly built, he was of impressive appearance; he had a piercing and very intelligent eye, a clear resonant voice, and a strong chin. $\mathrm{He}$ held decided views on most subjects and was always prepared to express them, and, if need be, to throw them overboard. He possessed a dry humour, well under control.

His publications included an elementary text-book on mathematics and one on fourfold geometry. $\mathrm{He}$ married in 1897 Jessy, daughter of Mr. William Philip. She survives him with a son and three daughters. Mrs. Mair was for many years secretary of the London School of Economics, and their eldest daughter is Dr. Lucy Mair, well known as an anthropologist.

Lennard Blaikie.

\section{WE regret to announce the following deaths :}

Prof. Kurt Brandenburg, professor of special pathology and therapy in the University of Berlin, editor of the Medizinische Klinik, aged seventy-three.

Dr. W. A. Bryan, director of the Los Angeles Museum of History, Science and Art, on June 18, aged sixty-six.

Prof. A. Döderlein, formerly professor of gynæcology and obstetrics in the University of Munich, a pioneer in the bacteriology of the puerperium, aged eighty-one.

Dr. Laurence S. Moyer, of the Department of Botany, University of Minnesota, known for his work on the biochemistry and physiology of plants.

Prof. Francis Ramaley, emeritus professor of biology in the University of Colorado, botanical editor of Ecology, on June 10, aged seventy-one.

Sir Montagu Sharpe, K.C., the well-known ornithologist, chairman of the Council of the Royal Society for the Protection of Birds, on August 23, aged eighty-five. 